\title{
Words and social change. The impact of power and ideology on the language of Economics and Law
}

\section{Simonetta Resta}

\section{CpenEdition}

\section{Journals}

\section{Electronic version}

URL: http://journals.openedition.org/asp/2760

DOI: 10.4000/asp.2760

ISSN: 2108-6354

\section{Publisher}

Groupe d'étude et de recherche en anglais de spécialité

\section{Printed version}

Date of publication: 1 December 1998

Number of pages: 89-98

ISSN: 1246-8185

\section{Electronic reference}

Simonetta Resta, « Words and social change. The impact of power and ideology on the language of Economics and Law », ASp [Online], 19-22 | 1998, Online since 02 March 2012, connection on 30 April 2019. URL : http://journals.openedition.org/asp/2760 ; DOI : 10.4000/asp.2760

This text was automatically generated on 30 April 2019.

Tous droits réservés 


\title{
Words and social change. The impact of power and ideology on the language of Economics and Law
}

\author{
Simonetta Resta
}

\section{Language is not merely the mirror of our society it is the major force in constructing what we perceive as reality. (Whorf 1956) ${ }^{1}$}

\section{Language}

\subsection{Language and power}

1 Language, in all cultures, fulfils a number of functions. It interprets the whole of our experience, reducing the infinitely varied phenomena of the world around us, as well as the worlds inside us, to a manageable number of classes of phenomena, types of processes, events and actions, classes of objects, people and institutions.

2 Language plays a vital role in what has been called the "social construction of reality" creating frames of consistency. Languages are systems of categories and rules based on fundamental principles and assumptions about the world. Whorf (1956) calls these assumptions science and metaphysics, immersed in life, which then generate an "ideology" defined as: "a systematic body of ideas organised from a particular point of view".Ideology is a conception of the world that implicitly manifests itself in law, ineconomic activity, in science and even in art, including political ideologies of various kinds. It can be located either in language structure or in language event.

3 Economic power struggles are associated with other predominant ideologies, in order to obtain a hegemony which represents leadership and power across the economical, political, cultural and ideological domains of a society; this is achieved not simply by dominating subordinate classes but by winning their consent through ideological means. 
This conception, according to Gramsci (1971), is implicit in the manifestation of individual as well as collective life in capitalist society, where common sense ideologies become naturalised, or automatic. They thereforebecome, as Fairclough (1989b: 2-4) suggests, "common sensical" and accepted as such. Language becomes an instrument of control and communication, linguistic forms allowing significance to be conveyed and distorted.

Foucault (1975) states that the constitutive power of modern society lies in the discursive practices of social institutions and organisations. These practices are often redesigned in accordance with particular strategies and objectives, usually those of politicians, managers, lawyers and bureaucrats. In practice, both legal and economic discourse reflect a position of power, and both are the language of those connected with power: bureaucrats, lawyers, managers, politicians or the press controlling discourses and practices and the ideological assumptions embedded in them.

5 Discourse operates within conventions defined by the discourse community, an academic discipline or social group. This type of discourse community, together with the concept of an interest group offers a more easily identifiable aspect of discourse, referring to a social occasion and the discursive practice thus generated. In addition, owing to register and genre, a discourse community acquires a specific lexis and uses one or more genres for topic, form, function and discoursal elements, which together form the "order of discourse".

6 If we try to follow the process by which meaning and concepts are generated, their language and practice at different levels reflect a position of power; they determine, influence and control discourses which, as social entities, interact dialectically with social structures to become universal and common sense. They thus create and enforce unbalanced and unequal power relations, drawing on discursive practices, whose heterogeneous relations produce interdiscoursivity as a merger of different discourse genres. ${ }^{3}$

7 The present article sets out to investigate power relations in legal and economic discourse and the way they create different orders of discourse, i.e., different networks of conventions which underlie, constrain and legitimise social and discursive practices. We will then show the different articulations of power in these two important fields of social life.

\subsection{Characteristics and varieties of legal language}

Language is central to law, and law as we know, is inconceivable without language. (Gibbons 1994: 3)

8 Language is central to human affairs, but it is particularly critical for the purposes of the law. In fact, in a very basic sense, law would not exist without language. There are two primary functions of the law: one is the ordering of human relations, the other the restoration of social order when it breaks down. With regard to the former, the function of the law is two-fold: regulative and constitutive. ${ }^{4}$ Law defines relations and tells us which activities are permitted and which are not; and by means of law, new relations are created where none existed before (e.g., marriage ceremonies). Through skilful drafting, the legislator hopes to be able to prevent litigation. ${ }^{5}$

9 Legal discourse as communicative process typically presents an interrelationship of power and truth or knowledge in terms of its self-articulation; legal discourse is 
paradigmatically concerned with truth, both in terms of evidence or verification and also, more generally, in terms of the definition or delimitation of power and powers in the discourse of rights, duties, capacities and procedural forms.

In his Concise Law Dictionary, Osborn (1993) defines common law as:

the common sense of the community, crystallised and formulated by our forefathers.

10 Hence, reading the law is not simply understanding the words of the text but also being aware of the tradition and wisdom that accompany them. ${ }^{6}$

11 Common law, at least the most fundamental system, was unwritten until the 15th century; the law was created by custom and precedent, stressing its proximity to God's will and to natural law preserved in parchment rolls or in formularies in various records and reports. ${ }^{7}$

Legal language as social discourse is a hierarchic, authoritarian, monologic and alien use of language and therefore obscure and archaic. Many historical, sociological, jurisprudential and political factors account for the evolution of legal language, which has become a unique variety of English.

\subsection{Linguistic approach to legal language}

The English legal tradition had to face the advent of printing and the problem posed by the public system of written laws and this soon developed into a field of expertise.

Linguistic studies alone do not explain why the language has become so complex and articulated. ${ }^{8}$ Most of its forms and structures seem old-fashioned in modern language use (for example, many contracts are not written afresh but reuse old formulas). The legal register is also characterised by long sentences (50 words on average), an impersonal style and typical legal vocabulary.

There is more to legal language, however, than specialised vocabulary. In terms of syntactic complexity,subordination and left-branching constructions are quite often found. Sentence length and sentence complexity seem to go together ${ }^{9}$ with a high frequency ofpassive constructions.

It is also interesting to point out the frequent occurrence of words likeadministration, disposition, distribution, etc., all clear examples of nominalisation, which also appears in scientific English but not with the same frequency as in legal English. Nevertheless, the function of legal language is a performative one, for as legal language carries the force of the law, the statement is the act. A person who has been pronounced guilty, is guilty. Similarly, When a divorce is granted, two married people are unmarried by a set of written words, and when a person has been reported missing for seven years, a court can declare him/her dead, the reality is irrelevant.

The freedom historically assumed and jealously retained by common law judges ensures that each judge speaks to some extent in his own voice. Individual styles vary considerably in judgements, according to thesocial gravity of the occasion or speech event. ${ }^{10}$ 


\subsection{Legal Language and legal meaning}

Legal language develops only through legal practice. It is the courts, legislatures, and government agencies that decide the legal meaning of terms, not ordinary usage and historical change.

A conspicuous number of legal studies consider legal language as the specifically and sociolinguistically defined usage of a particular speech community, spelling out the characteristic of legal genre:

a recognisable communicative event, characterised by a set of communicative purposes identified and understood by members of the professional or academic community in which it regularly occurs and is most often highly structured and conventionalised. (Bhatia 1993)

Goodrich, a legal scholar with a good foundation in linguistics, views law as a system of communication and the rhetoric of a particular group or class and also as a specific exercise of power, whose meaning and texts bear the imprint of such a practice and organisational background. (1987: 88)

The system operates by a process of inclusion and recognition of meaning, accent and connotation; also of exclusion, i.e., rejection of meaning, accent and connotation as unauthorised and threatening. This system acts in written documents such asstatutes and contracts, to include special provisions to define and interpret the words and concepts contained therein. For example, born means born alive (the moment of a child's birth being when it first has a life separate from its mother); birth has a corresponding meaning, and motor vehicle means a mechanically propelled vehicle intended or adapted for use on the road. ${ }^{11}$ Other legal definitions, mostly found in legal textbooks, are just expressions of the law, tightly controlling meanings and concepts, as in the following definition of a Will:

A will is a disposition or declaration by which the person making it provides for the distribution or administration of property after his death.

Substantive law, whose primary function is declaring the law, is expressed in decided cases, where the constraints and conventions of style and genre are strictly institutionalised. Thus some legal terms developed their meaning through litigation, e.g. the legal concept of negligence the meaning of which was later redefined through Appellate Court decisions which became leading cases like the famous Stevenson v. Donoghue. ${ }^{12}$

Linguistics alone cannot therefore provide any valid explanation for the use of legal jargon as it is the lawyers' tool and the only way to communicate within the legal community and interact and establish rules of behaviour that are mandatory for other social groups. It would therefore be inconceivable for a lawyer to express himself differently. If he did, the language would not be recognised by other members of the legal community, judges, lawyers and solicitors. ${ }^{13}$

There is a major distinction in legal language between the written and spoken word (Bhatia 1986). The power and the authority of written legal language, (Case Law, Statutes, Acts, etc.) has already been examined. We will touch briefly upon power relations in spoken legal language, mainly courtroom interaction, which has been the subject of investigation by many scholars such as Robin Lakoff (1975) and later O'Barr and Atkins (1980). They tried to single out the characteristics of powerful as against powerless speech, identifying the former with the speech of the educated male and the latter with the 
language of women and/or illiterate witnesses, often migrants. ${ }^{14}$ Likewise, the presence of either hesitations or hedges was sufficient to reduce a speaker's authoritativeness. A welleducated witness using a high-power style was more likely to be credible than an illiterate one.

\section{The language of enterprise and management}

English history over the past centuries has witnessed huge changes in social, economical and political structure, with the result that it is not easy to correlate the main social and semantic shifts. Historical sources reveal the different linguistic legacies, from the Norman conquest to Celtic and Norse invasions, to major Latin and clerical influxes. ${ }^{15}$

There emerges a clear sociolinguistic connection between social status or function of a speech community and the register and tone of the verbal legacy it has left. For example, words associated with the growth of Capitalism mirror the change from the feudal society of clergy, knights and serfs. Words such as fee, finance, purchase, profit, interest rate and market value reflectthegeneral trend of specialisation. The monetarisation of transactional terms like business, budget, duty, embezzle, finance and income previously had broader meanings before being absorbed into the financial field. Others are more restrictive terms imposed by the crown or the state up until 1550, such as: revenue, levy, debt, customs, excise, duty and monopoly control.

From 1550 onwards, the terms suggest a connection with money as a source of freedom: bank, trade and traffic, capital, cash, invest, exploitation and entrepreneur. ${ }^{16}$

In recent times, the onset of the enterprise society brings about changes in the language of money and capitalism. OED defines enterprise as "an engagement in bold, hazardous or momentous undertaking". Some other definitions are based on a more modern approach, seeing the management of resources and risks involved as "Disposition or readiness to engage in undertakings of difficulty, risk or danger and daring spirit".

Enterprise carries the stigma of the "ugly and unacceptable face of capitalism", whose principal aims are to maximise profit and keep tight control over it through globalisation, re-engineering and downsizing, and outsourcing. This view is counterbalanced, however, by "the caringface of capitalism", a different discourse which shows not only the evils but also the positive side of capitalism, embodied in the caring company who worries about the individual, looks after consumer and worker satisfaction, offering stable jobs to loyal workers and contributes to preserving a decent standard of living for their people. ${ }^{17}$ In the US, corporations are a very important issue, as they embody economic power. Their life mirrors the stages and events of human life from birth to death, companies merge with other companies as a symbolic economic wedding, they have children (parent companies). They also have a personality as firms are learning organisation, and they invest in knowledge networks. ${ }^{18}$ Following hard on the heels of new concepts and ideas, new words such as downsizing, restructuring, empowerment etc., are created to justify this behaviour. The metaphor of cutting expenses and getting rid of staff, making the firm slim and agile is pursued to extreme consequences with corporate anorexia as a "necessary" tool to keep the profits of the enterprise up and meet the approval of the shareholders. ${ }^{19}$ Likewise, corporations contribute to the creation of vocabularies containing words that reflect their ideologies, such as corporate loyalty, corporate culture, corporate tax, corporate life, corporate world, corporate lawyer, etc. They are oftendivided by 
two opposing tensions embodied in the two concepts, profitability versus employability. The major concern of modern management theory is to shift from shareholder to consumer and stakeholder satisfaction, wherethe interplay between management theorists, "gurus", and management trends, which they influence, becomes highly visible. Obviously the press has been giving greater coverage to these events. ${ }^{20}$ Irony and criticism are the bottom line of many articles contained in specialised economic magazines such as The Economist, which sometimes criticise the accepted trends of powerful institutions often required by the market ideology and therefore perfectly logical and full of common sense.

Economic issues are sometimes heavily biased by politically correct and other sociopolitical instances, where the use of words seems to play a more important role: downsizing or flexibility, sounds better than firing or giving the sack; words used to disguise the real substance of the action taken often sound euphemistic: a golden handshake, a golden boot, as these expressions usually hide the fact that managerial staff are being disposed of by offering them a sizeable amount of money.Similarly it is easier to speak about full employment and/or minimum wages, without mentioning that they have contributed to racial discrimination by creating a new American poor (often blacks and Hispanics). Discrimination against protected groups is illegal in America, ${ }^{21}$. but while there is no doubt that it exists, it "is devilishly difficult to pin down" 22

\section{Conclusion}

Language is like an archaeological site: the more you dig the more you find.

31 Language as viewed by sociolinguists is social practice, a mode of action, and is socially shaped but also socially shaping or constitutive. This article set out to explore both sides of language, focusing on modalities and structures used by the language of law and management to express power and control.

Legal discourse is more restrictive in terms of meaning as well as syntactic structure, both of which contribute to create a sense of precision and detachment. Moreover, legal language does not need to justify, nor to persuade, nor to canvass, because "the law is the law and everyone needs to abide by the law".

The language of management, as a relatively modern practice, endorses values created by capitalism and profit, using a more accessible language than law. It is often seductive and persuasive and also less prescriptive and formal than legal language, as it borrows the use of colour and metaphors from the language of advertising and marketing. Thus Business issues are usually shrouded in mysticism and emotive language, as for example in the following expressions taken from Key words in business (1997): junk bonds, corporate raiders, white knight, poison pill, green mail, golden boot, etc.

Socio-economic mutation affects language use, consequently, discursive practices are influenced by phenomena such as conversationalisation, commodification and cultural globalisation; socio-economic change inevitably modifies our socio-pragmatic bearings, so that the relationship between text and order of discourse becomes increasingly unsettled and ambiguous. ${ }^{23}$ Hence, management texts reveal in the detail of their linguistic choices the contradictory, unresolved and unfinished nature of the social practices they constitute. Linguistics and Pragmatics are therefore often inadequate, being too theoretical, to perform any analysis. They often seem to address an ideal world, whereas 
critical discourse analysis, as itis concerned with analysing discursive practices and conventions associated with institutions, proves more useful in detecting and understanding how social trends, and hence ideology, influence professional discourses, eliciting from them a system of meaning and a coherence based on common sense.

We have tried to demonstrate that we need to connect discoursal study with language teaching, in order to reach a better, deeper understanding of the social phenomena of contemporary society. Critical discourse awareness should be seen as a basis for social knowledge and understanding.

Whorf, B.L. 1956. Language Thought and Reality. Cambridge: MIT Press.

\section{BIBLIOGRAPHY}

Bhatia, V.J. 1994. “Legislative Writing”. In J. Gibbons (ed.), Language and the law. London: Longman.

Bhatia, V.J. 1993. Analysing Genre: Language use in the professional setting. London and New York: Longman.

Bondi Paganelli, M. \& G. Del Lungo. 1995. Analysing Economics and News Discourse. BolognaClueb. Corporate Culture and Performance. 1992. New York: Free Press.

Fairclough, N. 1989a. "Michel Foucault and the analysis of discourse". Centre for Language and Social life Research Paper 10, Lancaster University.

Fairclough, N. 1989b. "Language and Ideology". English Language Research Journal.

Fairclough, N. 1992. Discourse and Social Change ; Cambridge:Cambridge Polity Press.

Gibbons, J. (ed.). 1994. Language and the law. London: Longman.

Goodrich, P.1987. Legal Discourse. London: Macmillan.

Gramsci, A. 1971. Selection from the Prison Notebooks, ed. and trans. by Q. Hoare N. Smith. London: Lawrence \& Wishart.

Hodge, G. \& B. Kress. 1988. Language as Ideology. London \& Boston.

Jackson, B. S. 1995. Making sense in law. Liverpool: Debora Charles Pbs.

Key words in Business. 1997. London: Collins Cobuild.

Kress, B. \& T. Threadgold. 1988. “Toward a social theory of genre”. Southern Review, 21, 215-43.

Kurzon, D. 1985. "Clarity and word order in Oxford legislation". Oxford Journal of Legal Studies 5/2.

Mellinkoff, D. 1992. The language of the Law. Boston: Little Brown and Co.

Osborn's Concise Law Dictionary. 8th ed. 1993. [1927]. London: Sweet \& Maxwell.

Perrin, M. 1990. "De l'utilisation 'communicative' des documents authentiques". In Perrin \& Delorme (eds.), Langues de spécialité/langue pour le spécialiste : du linguistique au didactique, Actes du $\mathrm{XI}^{\mathrm{e}}$ colloque du GERAS. Bordeaux : Université Bordeaux 2, 9-33, 
Resta, S. 1996. "Case studies and case reports : Management and legal orientations to text". ASp

11-14, 55-74.

Resta, S. 1998. "Legal language or the language of the law. Linguistic and Legal Approaches". In Castorina G. et alii, Texts and Tools. Bologna: Monduzzi.

Swales, J. 1993. Genre analysis. Cambridge: Cambridge University Press.

\section{NOTES}

1. The Whorfian hypothesis states that each language possesses a structure which must, at some level, influence the way the user views the world. This issue has important implications for the discourse community and the use of discourse conventions.

2. For the definition of discourse community, see Swales (1990: 23-32).

3. The issue of whether a community's discourse and its expectations are constitutive or regulative of the world view is still open to debate: does participation entail assimilation? We will try to give an answer to this crucial question.

4. Legal discourse too has both a constitutive and regulative nature.

5. The functions of the law are also defined as law making (statutes, acts and case law), law applying (the judge applying the law in court)and law describing activities (legal research, professional journals and textbooks).

6. An interesting example is offered in one of the first legal dictionaries, The Interpreter, by $\mathrm{Dr}$ John Cowell (1607), professor at Civil Law at Cambridge. This is one of the many works which attempted to systematise common law and contains the following statement of general principle: "Indeed a lawyer professes true philosophy, and therefore should not be ignorant of either fowls, beasts or creeping things, nor of the trees from cedar in Lebanon or to the Hyssop that spring out of the wall."

7. Traditio in the ecclesiastical sense is an authoritative knowledge handed down through manuscriptural or printed text, having custody of the common law in the sense that the natural quality of law will go beyond individual texts and writings. Equally, the word equity originates from Latin aequitas and designs a vicarious system of the common law.

8. Studies of the structural properties of the register of legal English have labelled the style as formal or frozen due to formulae and/or references to other provisions (see Resta,1990).

9. Gustafsson (1975) reports an average of 2.86 clauses per sentence.

10. A consistently formal tenor is typical, particularly in the written appellate judgements that form the core of case law. In the English higher courts, formal modes of address are retained, even in the published reports, and the judges refer to their "learned brethren" as "my noble and learned friend".

11. The Congenital Disabilities (Civil Liability) Act 1976, subsection 2 of Section 3 (see cap 3.5).

12. "... the doing of something which a reasonably prudent person would not do, or the failure to do something which a reasonably prudent person would do under a given set of circumstances".

13. The problems created by the obscurity and complexity of legal language have been taken up by a number of sociologists, scientists and consumer protection advocates from different countries who have hotly debated the need to reform legal and bureaucratic language to make it plain and more intelligible to the lay person.

14. These statements are not value judgements but are based on what goes on in the court room.

15. The words cell, office, propaganda and sanction are common secular words with clearly developed scientific, commercial and political denotations or prime meanings, yet all have a 
common ecclesiastical origin: cell derives from the monastery, propaganda from counter-reform liturgy, sanction from imposition and penance.

16. Some terms carry unfavourable connotations, like middleman, who was invariably suspected of profiteering, hence broker was used with hostility and contempt. See Hodge and Kress (1988).

17. Now, due to mergers and take-overs, the life of a company can be very short so,"Companies may not owe one a job for life but they have the responsibility to train their workers so that they have a better chance of finding a new job. This is the concept of employability, which, is appealing to the corporate world as ... a fluffy compromise". See Corporate Culture and Performance Published by Free Press 1992.

18. The motto of many companies such as IBM was "think" and sensible bosses always valued the accumulated skills of their workers. See Wellsprings of Knowledge, Harvard Business School Press, 1995.

19. Following this trend, companies in the US startedto slash their labour forces. Immediately, other firms in the US and Europe followed suit without paying much attention to the social or moral effects of their actions.

20. To begin with, the cold and rational approach of Milton Friedman, whose motto: Business is business, legitimates all actions and misdeeds carried out by executives, such as sacrificing workers on the altar of profitability; then, that of Peter Drucker, who gave management theory a scientific approach. Later this was subverted by more humanitarian theories that saw companies as membership communities, able to offer workers job security, in exchange for a fuzzy kind of loyalty.See the article, in The Economist. (Civic 101 the Economist 1996) "Do companies have social responsibilities?".

21. In the U.S. it is illegal to treat female job applicants differently from males or to refuse to rent flats to Hispanics or refuse a mortgage to blacks but these people are nevertheless less likely to get jobs, mortgages, houses, etc.

22. See The Economist June 61998, "Race, sex and dismal science." Here the author asks the question: Are these inequalities due to deliberate discrimination or are other factors at work? And he concludes: Economic analysis cannot provide an answer.

23. For the concept of order of discourse, see Fairclough (1989a: 17). The actual discourse is determined by socially constituted orders of discourse, sets of conventions associated with social institutions.

\section{ABSTRACTS}

Discourse is a category used by social theorists, analysts and linguists and any investigation implies a view of language as social practice, always related socially and historically to its context. Thus language is not only socially shaped but socially shaping and its use is constitutive of social identities, social relations and knowledge, giving rise to complex discourse practices and discourse conventions influencing Law and Management, and creating interdiscourses and intertextuality at textual level. We therefore require not only linguistic but also intertextual analysis, what Fairclough calls critical discourse analysis, to shed light on relationships between discourse practices, and show how they are influenced by social and economic processes. Social change and its impact on language use calls for a redefinition of the concept of LSP (Language for 
Specific Purposes) and the role of the language teacher, the mediator between language and culture.

Le terme «discours" est employé par les sociologues, et par les linguistes. Toute étude de discours doit entendre le langage comme pratique sociale, toujours liée, socialement et historiquement, à son contexte. Ainsi, non seulement, le langage est déterminé par son contexte social, mais il exerce aussi une influence qui construit ce contexte. Son utilisation constitue les identités, les relations et les connaissances sociales. Celles-ci, à leur tour, donnent naissance à de complexes pratiques et usages qui influencent les domaines du droit et du management en créant des «interdiscours » et de l'intertextualité. Nous devons, par conséquent, mener une analyse aussi bien linguistique qu'intertextuelle, ce que Fairclough appelle " critical discourse analysis ", afin d'éclaircir les relations entre les différentes pratiques du discours et montrer de quelle manière elles sont influencées par les processus sociaux et économiques. L'évolution sociale et son effet sur l'utilisation du langage nécessitent une redéfinition du concept de LSP (Langue de spécialité) et du rôle du professeur de langues, médiateur entre langage et culture.

\section{INDEX}

Mots-clés: culture, discours, évolution sociale, intertextualité, langage, common law

Keywords: discourse, intertextuality, language, social change

\section{AUTHOR}

\section{SIMONETTA RESTA}

Simonetta Resta est professeur d'anglais à la Faculté d'économie de l'Université de Rome la Sapienza. Elle s'interesse à la traduction et à la traductologie, ainsi qu'à l'analyse du discours du point de vue descriptif et didactique, en particulier du discours juridique et économique. Parmi ses publications, une monographie dans Text and Tools, Legal English publié par Monduzzi Editore, Bologna.simonettaresta@yahoo.com 